\title{
AMMONIA EMISSION REDUCTION MEASURES IN DAIRY CATTLE FARMING
}

\author{
Juris Priekulis ${ }^{1}$, Armins Laurs ${ }^{1}$, Ligita Melece ${ }^{2}$ \\ ${ }^{1}$ Latvia University of Life Sciences and Technologies, Latvia; \\ ${ }^{2}$ Institute of Agricultural Resources and Economics, Latvia \\ juris.priekulis@1lu.lv, arminslaurs@inbox.lv, ligita.melece@arei.lv
}

\begin{abstract}
The article discusses the possibilities of ammonia emission reduction in dairy cattle farming. In earlier research by the authors of the article it has been found that updating of the production technology and production of liquid manure increase ammonia emissions approximately 1.8 times. Therefore, it may hinder implementation of the national aims determined in the country on a gradual reduction of ammonia emissions. Therefore, the ammonia emission reduction measures recommended in special literature are summarised as well as their evaluation by application of the expert method is presented. The measures approved by the experts are divided into three groups depending on the capital investments that are needed for their implementation. In the research it has been stated that for further reduction of ammonia emissions in dairy farming it is sufficient to improve the animal welfare measures and enlarge usage of liquid manure chemical or biological additives, but it is not necessary to invest large capital investments for the building of new dairy cattle housing facilities and farm manure storages.
\end{abstract}

Keywords: ammonia emissions, dairy cattle, liquid manure.

\section{Introduction}

Dairy cattle farming is one of the most important branches of agriculture in Latvia, which gives on average $24 \%$ of the total income from agriculture [1]. Besides, today gradual updating of this branch is taking place. For instance, in all large dairy cattle farms today liquid manure is produced and its volume increases every year by approximately $2.5 \%$ [2]. Compared to solid manure, it is easier to mechanise management of liquid manure, necessity for litter material essentially reduces and consumption of work on the farm also reduces. Nevertheless, the earlier research by the authors of the article [3] shows that introducing loose handling of dairy cattle and producing liquid manure the area of dirty and wet floor in the farm increases by approximately three times. It increases ammonia emissions. This trend is observed not only in Latvia, but also elsewhere in the world. For instance, Fangueiro et al. [4] stressed that ammonia emissions are a major problem associated with animal slurry management, but Bougouin et al. [5] indicated that liquid manure management systems had greater ammonia emissions than slatted or solid floors in barns. This situation is also affirmed by the calculations of the authors of the article using the methodology Tier 2 [6]. The calculations show that transition to loose handling of cows and production of liquid manure increase the total ammonia emissions from manure produced on the farm and stored in storages approximately 1.8 times.

Therefore, implementation of the national aims stated in the country, which envisage a yearly reduction of ammonia emissions by $1 \%$ per year $[7 ; 8]$, is in danger. In order to improve the situation and reduce ammonia emissions by the implementation of additional measures that are indicated in special literature, for instance, the measures described in the recommendations of the United Nations Economic Commission for Europe (UNECE) Task Force on Reactive Nitrogen [9-11]. Though, not all of these measures are suitable for implementation in the circumstances of our country.

Therefore, the aim of the present research is to state the most suitable measures for ammonia emission reduction that could be implemented in Latvia's dairy cattle farms, where loose housing is used and liquid manure is produced.

\section{Materials and methods}

In order to size up the present situation information was summarised on the farm manure management technologies that are used in dairy farming [12] as well as literature data were gathered about the possible sources of ammonia emissions, the measures to reduce these emissions and the possible volumes of their reduction [9-11]. For evaluation of this information the expert method was applied [13]. For this purpose the survey questionnaire for experts was created, where the potential measures of reduction of ammonia emissions that are caused by the removal of manure from dairy cattle housing facilities and storage of manure had been included. There were not only questions about 
the priority of implementation of the corresponding measure, but also the necessary state support needed for implementation of the measures included in the survey questionnaire.

Altogether there were two groups of questions - on the emission reduction measures in cold barns and in liquid manure storages.

For evaluation of every group of questions 12-15 experts were involved. They were external experts from the Latvian Rural Advisory and Training Centre, the Latvia University of Agriculture and the specialists working in the large animal breeding farms. The Internet was used to send the survey questionnaires and to receive the replies. For processing of the obtained information the methods described in the literature $[14 ; 15]$ were applied. Accordingly the priority range of every emission reduction measure was determined and the measures that are suitable for the conditions of Latvia were stated.

Nevertheless, all emission reduction measures that can be introduced in dairy cattle housing vary according to the character of their introduction and the possibilities of the farms. Therefore, they can be divided in three groups.

- Group I. Measures that do not require large capital investments, but it is mainly sufficient to improve the organisation of work.

- Group II. Measures the introduction of which requires reconstruction of the dairy cattle housing facilities, but the state support for it is not needed.

- Group III. Measures involving essential reconstruction of the dairy cattle housing facilities, and therefore the state financial support is needed.

For this reason all emission reduction measures approved by the experts were additionally divided in the three above mentioned groups and for every group the possible emission reduction coefficient was calculated using the formula

$$
K_{s}=k_{s 1} \cdot k_{s 2} \cdots k_{s n}=\left(1-\frac{S_{1}}{100}\right) \cdot\left(1-\frac{S_{2}}{100}\right) \cdots\left(1-\frac{S_{n}}{100}\right),
$$

where $K_{s}$-emission reduction coefficient for the corresponding group of measures;

$k_{s 1}, k_{\mathrm{s} 2} \ldots k_{s n}$ - emission reduction coefficients for every corresponding measure of emission reduction in one group;

$S_{1}, S_{2} \ldots S_{n}$ - amount of ammonia emissions' reduction by implementation of each corresponding measure, $\%$.

For approximate calculations these data can be taken from the literature [9-11]. Besides, if this reduction is given in a definite interval, in the calculations its average value was used.

\section{Results and discussion}

The research results are summarised in the tables below. They show the definite ammonia emission reduction measures, their priority evaluation (range) in accordance with the expert survey data, emission reduction obtained in the result of implementation of the measures (according to the data in literature), as well as the priority group of the corresponding measure.

Table 1 shows that in dairy cattle cold barns it is essential to use moisture absorbing materials for animal bedding, for instance, straw litter. It means that possibly deep boxes with manure - straw bedding should be used. Besides, farm manure should be removed regularly $[5 ; 11 ; 17]$.

Decreasing the duration of cattle in housing and increasing the grazing period are suitable techniques to reduce emissions $[9 ; 11 ; 17]$. As far as possible, grazing of dry dairy cows and young cattle could be practiced [16;17]. Within limits pasturing of dry cows and young dairy cattle (i.e., calves) should be practiced.

Building new milk dairy cattle housing facilities or reconstructing the old ones, it is advisable to install efficient ventilation systems, build roofs with heat insulation and install manure ducts with deeply grid floors [16]. 
Evaluation of emission reduction measures for dairy housing

\begin{tabular}{|c|c|c|c|}
\hline $\begin{array}{l}\text { Priority } \\
\text { range }\end{array}$ & Solution of emission reduction measure & $\begin{array}{c}\text { Reduction of } \\
\text { emissions, \% } \\
{[9-11 ; 16]}\end{array}$ & $\begin{array}{l}\text { Priority } \\
\text { group }\end{array}$ \\
\hline 1. & $\begin{array}{l}\text { Usage of moisture absorbing material for animal } \\
\text { bedding, for instance, straw litter }\end{array}$ & $\sim 70 \%$ & $\mathrm{I}$ \\
\hline 2. & $\begin{array}{l}\text { Removal of farm manure at least } 2 \text { times per day in } \\
\text { shallow barns }\end{array}$ & up to $20 \%$ & I \\
\hline 3. & Pasturing of dry cows and young stock & up to $20 \%$ & I \\
\hline 4. & $\begin{array}{c}\text { Application of liquid manure chemical or biological } \\
\text { additives }\end{array}$ & up to $68 \%$ & I \\
\hline 5. & $\begin{array}{l}\text { Aerating the barns effectively using the influence of the } \\
\text { wind and installing roofs with heat insulation }\end{array}$ & $20 \%$ & II \\
\hline 6. & Introduction of manure ducts with deep grooved floors & $25-46 \%$ & II \\
\hline 7. & $\begin{array}{c}\text { Usage of barns with grid floors and underfloor manure } \\
\text { storage }\end{array}$ & $25-64 \%$ & III \\
\hline
\end{tabular}

Considerable effect is achieved also by usage of liquid manure chemical and biological additives that reduce the smell and gas emissions as well as improve decomposition of liquid manure solid admixtures (straw litter).

Several scholars $[4 ; 19 ; 20]$ stressed that cattle slurry acidification minimises ammonia emissions and following manure application. Furthermore, they point out that acidification of liquid manure increases the plant available nitrogen.

The results of evaluation of ammonia emission reduction measures for liquid manure storages are presented in Table 2. Stocking liquid manure, it should be taken into consideration that it should be entered under a natural or artificially designed covering, so that it does not disrupt the incoming stream of manure. However, usually this requirement is met, as it is included in the Regulations of the Cabinet of Ministers No. 829 [20]. Therefore, calculating the coefficient of emission reduction, this emission reduction measure was not considered.

Table 2

Evaluation of emission reduction measures for liquid manure storages

\begin{tabular}{|c|c|c|c|}
\hline $\begin{array}{c}\text { Priority } \\
\text { range }\end{array}$ & Solution of emission reduction measure & $\begin{array}{c}\text { Reduction of } \\
\text { emissions, \% [6-8] }\end{array}$ & $\begin{array}{c}\text { Priority } \\
\text { group }\end{array}$ \\
\hline 1. & $\begin{array}{c}\text { Feeding of liquid manure under natural or } \\
\text { manufactured covering layer * }\end{array}$ & $\sim 40 \%$ & I* \\
\hline 2. & $\begin{array}{c}\text { Application of liquid manure chemical or biological } \\
\text { additives }\end{array}$ & up to $68 \%$ & I \\
\hline 3. & $\begin{array}{c}\text { Installation of light construction roofs on cylindrical } \\
\text { liquid manure storages }\end{array}$ & up to $80 \%$ & II \\
\hline 4. & $\begin{array}{c}\text { Replacing of lagoon type storages with cylindrical } \\
\text { storages }\end{array}$ & $30-60$ & III \\
\hline 5. & $\begin{array}{c}\text { Reduction of liquid manure surface (mirror surface) } \\
\text { in newly built storages }\end{array}$ & up to $60 \%$ & III \\
\hline
\end{tabular}

*measure included in the Regulations of the Cabinet of Ministers No. 829 [20].

Another important measure of ammonia emission reduction from liquid manure is usage of chemical or biological additives, for instance, GÜLLEMAX or others. It is even better, if such additives are added already in the animal housing facilities. Then their influence continues also in the manure storage. There is another possibility to install light construction roofs over cylindrical liquid manure storages and to replace the lagoon type storages with cylindrical storages. Other investigations by the authors of the article show [21] that it is rational to build possibly deep lagoons, which have 
approximately equal length of the side walls. For all that, such changes require comparatively large capital investments and therefore can be implemented only in the future.

Total evaluation of the calculated emission reduction measures is given in Figure 1.

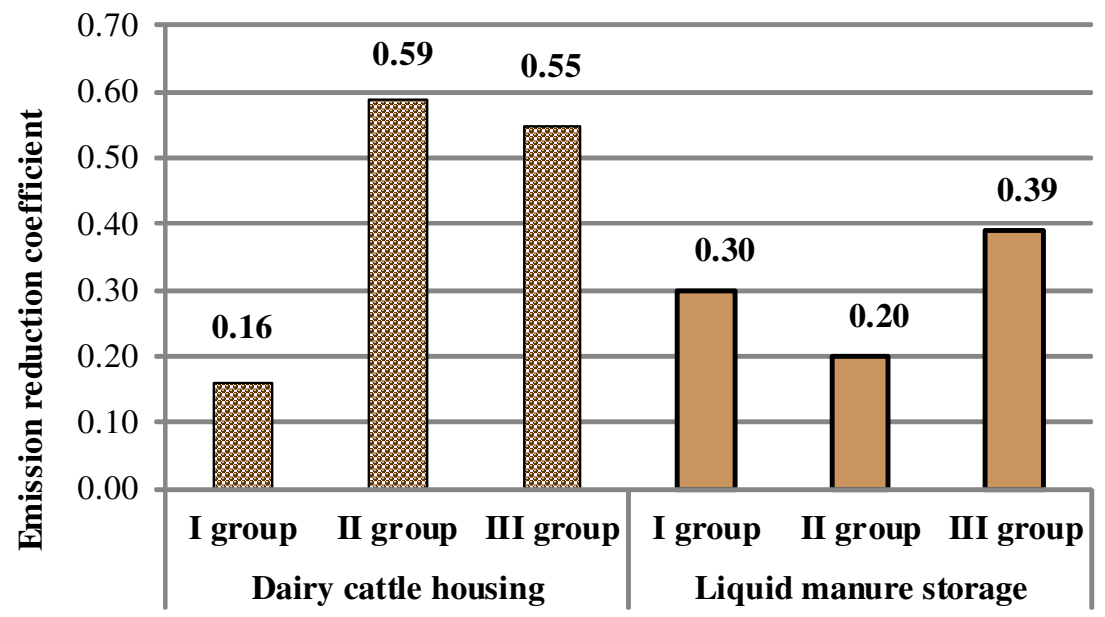

Fig. 1. Coefficients of ammonia emission reduction by implementing measures of various priority groups in dairy cattle farming

The figure shows that it is possible to achieve comparatively large ammonia emission reduction already with implementation of the measures of group I that are related to improvement of the welfare of animals as well as usage of liquid manure chemical or biological additives. Besides, their implementation does not require large capital investments.

Therefore, immediate implementation of the measures of groups II and III to reconstruct the existing housing facilities or liquid manure storages, or to build new ones, is not necessary as the obtained reduction of emissions is not always less compared to the implementation of the above mentioned measures of group I.

\section{Conclusions}

1. Most promising for dairy cattle housing are the following measures of group II and group III with the highest emission reduction coefficients (ERC). Accordingly, group II measures: 1) aerating the barns effectively using the influence of the wind and installing roofs with heat insulation and of manure ducts with deep grooved floors (ERC - 0.59); and 2) group III measure - the usage of barns with grid floors and underfloor manure storage (ERC - 0.55).

2. For liquid manure storages the highest ranked are the measures of: group I - feeding of liquid manure under a natural or manufactured covering layer (ERC - 0.30); and group III measures: 1) replacing of lagoon type storages with cylindrical storages, as well as 2) reduction of liquid manure surface (mirror surface) in newly built storages (ERC -0.39 ).

3. In order to ensure further reduction of ammonia emissions in dairy cattle farming on the first stage it is sufficient to implement the measures for animal welfare improvement and to enlarge the usage of chemical or biological additives for liquid manure.

\section{References}

[1] LR Zemkopības ministrija. Latvijas lauksaimniecība - gada ziṇojums (Latvian AgricultureAnnual Report). Riga: Ministry of Agriculture, 2018. 180 p. (In Latvian). [online] [31.01.2019]. Available at: www.zm.gov.lv

[2] Priekulis J., Aboltins A. Calculation of amount of farm manure. W. Romaniuk (Eds.) Problems of intensification of animal production including environment protection and alternative energy production as well as biogas. Warsaw: Falenty, 2016, pp. 147-151.

[3] Priekulis J., Melece L. Ammonia emissions reduction possibilities from dairy farms. Productivity of rotary parlours. Proceedings of International Scientific Conference "Engineering for rural development". May 23-25, 2018, Jelgava, Latvia, pp. 52-56. 
[4] Fangueiro, D., Hjorth, M., Gioelli, F. (2015). Acidification of animal slurry-a review. Journal of environmental management, vol. 149, 2015, pp. 46-56.

[5] Bougouin, A., Leytem, A., Dijkstra, J., Dungan, R. S., Kebreab, E. Nutritional and environmental effects on ammonia emissions from dairy cattle housing: A meta-analysis. Journal of environmental quality, vol. 45(4), 2016, 1123-1132.

[6] Frolova O., Priekulis J, Berzina L. Analysis of ammonia emission in different farming practises. W. Romaniuk (Eds.) Problems of intensification of animal production including environment protection and alternative energy production as well as biogas. Warsaw: Falenty, 2017, pp. 64-67.

[7] Directive (EU) 2016/2284 of the European Parliament and of the Council of 14 December 2016 on the reduction of national emissions of certain atmospheric pollutants, amending Directive 2003/35/EC and repealing Directive 2001/81/EC. Official Journal of the European Union, L 344, pp. 1-31.

[8] Ministru kabineta noteikumi Nr. 614 "Kopējo gaisu piesārņojošo vielu emisiju samazināšanas un uzskaites noteikumi" (Regulations No. 614 of the Cabinet of Ministers "Rules for the reduction and accounting of emissions of total air pollutants"). (In Latvian). [online] [15.12.2018]. Available at: https://likumi.lv.

[9] UNECE. Guidance document on preventing and abating ammonia emissions from agricultural sources. ECE/EB.AIR/120. [online] [9.01.2018]. Available at: https://www.unece.org.

[10] UNECE. Framework Code for Good Agricultural Practice for Reducing Ammonia Emissions. [online] [7.02.2018.]. Available at: https://www.unece.org.

[11] Bittman, S., Dedina, M., Howard C.M., Oenema, O., Sutton, M.A. (Eds). Options for ammonia mitigation: Guidance from the UNECE Task Force on Reactive Nitrogen. Edinburgh, UK: Centre for Ecology and Hydrology, 2014. 96 p.

[12]Laurs, A., Priekulis, J., Markovics, Z., Aboltins, A. Research in farm animal breeding technological parameters. Proceedings of International Conference "Engineering for rural development", May 25-27, 2016, Jelgava, Latvia, pp. 1054-1058.

[13].Markovičs Z. Ekspertu novērtējumu metodes (Expert Evaluation Methods). Riga: RTU, 2009. 111 p. (in Latvian).

[14] Hand D.J., Heikki M., Smyth P. Principles of data mining (adaptive computation and machine learning). Cambridge: MIT Press, 2001. 425 p.

[15] Tan P.N., Steinbach M. Introduction to Data Mining. Boston: Pearson Education, 2006. 769 p.

[16] Melece, L., Priekulis, J., Āboltiņšs, A., Jonkus, D., Laurs, A., Krieviņa, A., Pecka, A., Hāzners, J. Amonjaka emisiju ierobežošanas un samazināšanas pasākumu izvēles pamatojums lauksaimniecībā un to efektivitātes novērtējums (The selection and assessment of effectiveness of ammonia emissions mitigation and reduction measures in agriculture)., Report of 2 nd stage of MoA project No 10.9.1-11/17/886. Riga: AREI, 2017. 79 p. (In Latvian).

[17]Loyon, L., Burton, C. H., Misselbrook, T., Webb, J., Philippe, F. X., Aguilar, M., Bonmati, A. Best available technology for European livestock farms: Availability, effectiveness and uptake. Journal of environmental management, vol. 166, 2016, pp. 1-11.

[18] Fangueiro, D., Pereira, J., Bichana, A., Surgy, S., Cabral, F., Coutinho, J. Effects of cattle-slurry treatment by acidification and separation on nitrogen dynamics and global warming potential after surface application to an acidic soil. Journal of environmental management, vol. 162, 2015, pp. 1-8.

[19] Joubin, M. Animal slurry acidification: effects of slurry characteristics, use of different acids, slurry pH buffering. Uppsala: RISE Research Institutes of Sweden, 2018. 40 p.

[20] MK noteikumi Nr.829 "Īpašas prasības piesārņojošo darbību veikšanai dzīvnieku novietnēs" (Regulations No. 829 of the Cabinet of Ministers "Special requirements for performing polluting activities in animal farms"). (In Latvian). [online] [8.11.2018]. Available at: https://likumi.lv.

[21] Aboltins, A., Priekulis, J., Aboltina, B., Melece, L. Effect of slurry lagoon redesign on reduction of ammonia emission during livestock manure storage. Agronomy Research, vol. 15(5), 2017, pp. $1822-1830$ 